\title{
Michèle Clément, La «Mythistoire barragouyne de Fanfreluche et Gaudichon» ou comment inventer une "prose poétique»
}

\section{Filippo Fonio}

\section{(2) OpenEdition \\ Journals}

\section{Edizione digitale}

URL: http://journals.openedition.org/studifrancesi/27396

DOI: 10.4000/studifrancesi.27396

ISSN: 2421-5856

\section{Editore}

Rosenberg \& Sellier

\section{Edizione cartacea}

Data di pubblicazione: 31 décembre 2006

Paginazione: 590

ISSN: 0039-2944

\section{Notizia bibliografica digitale}

Filippo Fonio, « Michèle Clément, La «Mythistoire barragouyne de Fanfreluche et Gaudichon» ou comment inventer une «prose poétique» », Studi Francesi [Online], 150 (L | III) | 2006, online dal 30 novembre 2015, consultato il 08 novembre 2020. URL : http://journals.openedition.org/studifrancesi/27396 ; DOI : https://doi.org/10.4000/studifrancesi.27396

\section{Questo documento è stato generato automaticamente il 8 novembre 2020.}

\section{cc) $($ ) $\ominus$}

Studi Francesi è distribuita con Licenza Creative Commons Attribuzione - Non commerciale - Non opere derivate 4.0 Internazionale. 


\title{
Michèle Clément, La «Mythistoire barragouyne de Fanfreluche et Gaudichon» ou comment inventer une «prose poétique»
}

\author{
Filippo Fonio
}

\section{NOTIZIA}

MICHÈLE CLÉMENT, La «Mythistoire barragouyne de Fanfreluche et Gaudichon» ou comment inventer une «prose poétique», «Bibliothèque d'Humanisme et Renaissance», LXVII, 3 (2005), pp. 561-573.

1 La Mythistoire barragouyne de Fanfreluche et Gaudichon è tradizionalmente considerata un pastiche da Rabelais, con ogni probabilità (ed è la tesi che abbraccia anche la studiosa) a firma di Guillaume Des Autels. Il contributo si propone di ridimensionare tale giudizio, concentrandosi sugli aspetti originali e programmatici dell'opera come messa in atto di una teoria della prosa di finzione indipendente dal modello rabelaisiano. Numerosi sono i punti di contatto fra la Mythistoire (la cui edizione è attesa a breve) e il dibattito coevo sulla prosa volgare e sul valore della finzione rispetto alla storia. La studiosa riconosce, in particolare nel Proesme, l'influsso di Luciano, del De Philologia di Budé e della Poetica di Aristotele (il che starebbe a indicare una riscoperta del trattato aristotelico da parte dell'umanesimo francese anteriore rispetto a quanto finora postulato), nonché della Replique de Guillaume des Autelz aux furieuses defenses de Louis Meigret (1551), oltre a una precisa presa di posizione per un rifiuto del preziosismo, della lunghezza delle Amadis, della prosa epica di Jean Lemaire de Belges e della Franciade, dei precetti di Du Bellay. La Mythistoire si presenta già in limine come un romanzo di cavalleria burlesco e una parodia del petrarchismo e dell'amore platonico. La studiosa propone fra l'altro una lettura del titolo dell'opera, dell'aggettivo 
barragouyne in particolare, da intendersi come un'indicazione di poetica e un'attestazione dell'importanza del femminile nella Mythistoire, altro elemento che la identifica come qualcosa di più di un centone rabelaisiano. 